\title{
Functional Properties of Motoneurons Derived from Mouse Embryonic Stem Cells
}

\author{
Gareth B. Miles, ${ }^{1}$ Damien C. Yohn, ${ }^{1}$ Hynek Wichterle, ${ }^{3}$ Thomas M. Jessell, ${ }^{3}$ Victor F. Rafuse, ${ }^{1}$ and \\ Robert M. Brownstone ${ }^{1,2}$ \\ Departments of ${ }^{1}$ Anatomy and Neurobiology and ${ }^{2}$ Surgery (Neurosurgery), Dalhousie University, Halifax, Nova Scotia, Canada B3H 4H7, and ${ }^{3}$ Centre for \\ Neurobiology and Behaviour, Columbia University, New York, New York 10032
}

The capacity of embryonic stem (ES) cells to form functional motoneurons (MNs) and appropriate connections with muscle was investigated in vitro. ES cells were obtained from a transgenic mouse line in which the gene for enhanced green fluorescent protein (eGFP) is expressed under the control of the promotor of the MN specific homeobox gene $\mathrm{Hb}$ 9. ES cells were exposed to retinoic acid (RA) and sonic hedgehog agonist (Hh-Ag1.3) to stimulate differentiation into MNs marked by expression of eGFP and the cholinergic transmitter synthetic enzyme choline acetyltransferase. Whole-cell patch-clamp recordings were made from eGFP-labeled cells to investigate the development of functional characteristics of MNs. In voltage-clamp mode, currents, including EPSCs, were recorded in response to exogenous applications of GABA, glycine, and glutamate. EGFP-labeled neurons also express voltage-activated ion channels including fast-inactivating $\mathrm{Na}^{+}$channels, delayed rectifier and $\mathrm{I}_{\mathrm{A}}$-type $\mathrm{K}^{+}$channels, and $\mathrm{Ca}^{2+}$ channels. Current-clamp recordings demonstrated that eGFP-positive neurons generate repetitive trains of action potentials and that $\mathrm{L}$-type $\mathrm{Ca}^{2+}$ channels mediate sustained depolarizations. When cocultured with a muscle cell line, clustering of acetylcholine receptors on muscle fibers adjacent to developing axons was seen. Intracellular recordings of muscle fibers adjacent to eGFP-positive axons revealed endplate potentials that increased in amplitude and frequency after glutamate application and were sensitive to TTX and curare. In summary, our findings demonstrate that MNs derived from ES cells develop appropriate transmitter receptors, intrinsic properties necessary for appropriate patterns of action potential firing and functional synapses with muscle fibers.

Key words: amyotrophic lateral sclerosis; neuromuscular junction; electrophysiology; development; Hb9; synaptogenesis

\section{Introduction}

Embryonic stem (ES) cells are pluripotent cells with the capacity for continuous self-renewal. Recent advances in ES cell technology have permitted the derivation of neural progenitors from human ES cells (Reubinoff et al., 2001; Zhang et al., 2001), highlighting their potential as an unlimited cellular source for neural cell replacement therapies. Considerable attention has focused on the role of ES cells or their derivatives in the treatment of neurodegenerative disorders, such as Parkinson's disease and amyotrophic lateral sclerosis, in which selective populations of neurons degenerate (Arenas, 2002; Freed, 2002; Gerlach et al., 2002; Silani et al., 2002).

The differentiation of ES cells into dopaminergic neurons

Received March 26, 2004; revised July 15, 2004; accepted July 17, 2004.

This work was supported by Project ALS and the Atlantic Canada Opportunities Agency through the Atlantic Innovation Fund. G.B.M. is supported by a New Zealand Foundation for Research Science and Technology postdoctoral fellowship (DALH0201). T.M.J. is an investigator of the Howard Hughes Medical Institute and is supported by Project ALS, Wings Over Wall Street, and the Jewett foundation. We thank Curis Inc. for the supply of HhAg1.3, provided under the auspices of an agreement with Project ALS.

Correspondence should be addressed to either of the following: Robert M. Brownstone, Department of Anatomy and Neurobiology, Faculty of Medicine, Sir Charles Tupper Medical Building, 14A-5850 College Street, Halifax, Nova Scotia, Canada B3H 4H7, E-mail: rob.brownstone@dal.ca; or Victor F. Rafuse, Department of Anatomy and Neurobiology, Faculty of Medicine, Sir Charles Tupper Medical Building, 5850 College Street, Halifax, Nova Scotia, Canada B3H 4H7, E-mail: victor.rafuse@dal.ca.

DOI:10.1523/JNEUROSCI.1972-04.2004

Copyright $\odot 2004$ Society for Neuroscience $\quad$ 0270-6474/04/247848-11\$15.00/0
(Kawasaki et al., 2000; Lee et al., 2000; Kim et al., 2002) and motoneurons (MNs) (Renoncourt et al., 1998; Wichterle et al., 2002) has recently been reported, primarily on the basis of molecular markers. Additional critical aspects of neuronal subtype differentiation include the sensitivity of neurons to specific neurotransmitters, the ability to transform these chemical inputs into appropriate patterns of action potential firing, and the formation of functional synapses with target cells. Therefore, establishing the functional differentiation of ES cell-derived neurons will require a detailed comparison of the physiological properties of ES cell- and embryo-derived neurons. One prototypic neuronal population that may permit an analysis of this issue is the spinal MN (Binder et al., 1996; Heckman et al., 2003). In part, this is because many of the genetic cues that direct $\mathrm{MN}$ development have been defined. The combined actions of retinoic acid (RA) and sonic hedgehog (Shh) are thought to establish a profile of homeodomain transcription factors in ventral progenitor cells that is necessary for the subsequent differentiation of MNs (Briscoe et al., 2000; Novitch et al., 2003). These inductive signals and progenitor factors then direct the expression of downstream transcriptional regulators, in particular $\mathrm{Hb} 9$, a homeodomain protein expressed by postmitotic MNs (Thaler et al., 1999) that has been shown to consolidate MN identity (Arber et al., 1999).

Strikingly, many aspects of the normal developmental program that directs $\mathrm{MN}$ differentiation in vivo can be recapitulated 
using ES cells in vitro. Thus, exposure of ES cells to RA and Shh induces differentiation to neurons with many molecular markers of MNs (Wichterle et al., 2002). Such studies, however, have not yet resolved whether the molecular characteristics of ES cellderived MNs are accompanied by the acquisition of functional membrane properties typical of developing MNs: membrane currents, spike firing properties, and the formation of functional cholinergic synapses with muscle.

In this study, we have investigated whether the molecular properties of ES cell-derived MNs are accompanied by expression of characteristic MN physiology. We show that MNs derived from ES cells in vitro develop many functional properties of embryo-derived MNs in vivo: they express functional receptors for excitatory and inhibitory transmitter systems that normally provide inputs to MNs, they develop electrophysiological properties necessary to produce appropriate patterns of action potential firing, and they form functional cholinergic synapses with muscle cells in culture.

\section{Materials and Methods \\ Cell culture}

This study used an ES cell line (HBG3) derived from a transgenic mouse line ( $m H b 9-G f p 1 b)$ in which enhanced green fluorescent protein (eGFP) is expressed under the control of the mouse $\mathrm{Hb} 9$ promotor (Wichterle et al., 2002). Hb9 is a homeodomain protein that is expressed by somatic MNs (Arber et al., 1999; Thaler et al., 1999), and thus eGFP expression can be used to identify putative MNs in culture. ES cell-derived MNs were generated using methods described previously (Wichterle et al., 2002). Briefly, ES cells were grown in aggregate cultures for $2 \mathrm{~d}$ in DFK10 medium to form embryoid bodies (EBs). DFK10 medium consisted of DMEM (Specialty Media, Phillipsburg, NJ) and Ham's F-12 media (Specialty Media) in a 1:1 ratio supplemented with knock-out serum replacement ( $10 \%$ by volume; Invitrogen, Burlington, Ontario, Canada), penicillin/streptomycin ( $1 \%$ by volume; Sigma, St. Louis, MO), N2 supplement $(2.4 \%$ by volume; Invitrogen), glucose (4500 mg/l), L-glutamine (200 mM), heparin ( $1 \mathrm{u} / \mu \mathrm{l}$; Sigma), and $\beta$-mercaptoethanol (0.1 mm; Sigma). While in suspension culture, EBs were treated with retinoic acid ( $1 \mu \mathrm{M}$; Sigma) and hedgehog agonist (Hh-Ag1.3, $1 \mu \mathrm{M}$; Curis Inc., Cambridge, MA). EBs were cultured for an additional $5 \mathrm{~d}$.

To obtain stable recordings from ES cell-derived neurons, it was necessary to ensure that they adhered to coverslips. To do this, EBs were plated on day 5 on mitomycin C (Sigma)-treated primary mouse embryonic fibroblasts that had been plated 1-3 d previously on poly-D-lysinelaminin-coated $12 \mathrm{~mm}$ round coverslips (Becton Dickinson, Mississauga, Ontario, Canada) in DFK10 medium supplemented with $10 \%$ horse serum. For the remainder of experiments, EBs were plated on either the C2C12 muscle cell line (American Type Culture Collection, Manassas, VA) or chick myotubes. The $\mathrm{C} 2 \mathrm{C} 12$ cells were plated $10 \mathrm{~d}$ previously on poly-D-lysine-laminin-coated coverslips in myotube differentiation medium consisting of 98\% DMEM (Invitrogen), L-glutamine $(4 \mathrm{~mm})$, sodium bicarbonate $(1.5 \mathrm{gm} / \mathrm{l})$, D-glucose $(4.5 \mathrm{gm} /$ $1)$, and 2 or $10 \%$ horse serum. The chick myotube cultures were generated as described previously (Rafuse and Landmesser, 1996). Briefly, myoblasts were mechanically dissociated from embryonic day 12 (E12) White Leghorn chick pectoral muscles and diluted with culture medium to a final concentration of $10^{6}$ myoblasts $/ \mathrm{ml}$. Myoblasts were plated on rat tail collagen (type I; Collaborative Biomedical Products, Bedford, MA)coated coverslips at 50,000 cells per coverslip in $0.5 \mathrm{ml}$ of Ham's F-10 (supplemented with $1.26 \mathrm{mM} \mathrm{CaCl}_{2}$ ) containing $10 \%$ horse serum (Invitrogen) and $5 \%$ chicken embryo extract. After $2 \mathrm{~d}$ in culture, the cells were treated with cytosine $\beta$-D-arabinofuranoside ( $5 \mu \mathrm{M}$; Sigma) to remove the fibroblasts from the culture. Under these conditions, the cultures were devoid of fibroblasts and contained numerous multinucleated chick myotubes after $3 \mathrm{~d}$.

Medium for the EB-myotube cocultures consisted of DFK10 medium supplemented with $\mathrm{CaCl}_{2}(1.36 \mathrm{~mm})$ and sodium pyruvate $(1 \mathrm{~mm}$; Sigma). Twenty-four hours after EBs were plated, media were supple-
Table 1. Primary antibodies

\begin{tabular}{llll}
\hline Antiserum & Host species & Dilution & Source \\
\hline ChAT & Rabbit & $1: 250$ & 1 \\
MAP2 & Rabbit & $1: 2000$ & 1 \\
VAChT & Goat & $1: 10,000$ & 2 \\
\hline
\end{tabular}

Sources: 1, Chemicon (Temecula, CA); 2, Becton Dickinson.

Table 2. Secondary antibodies

\begin{tabular}{llll}
\hline Secondary & Dilution & Fluorophore & Source \\
\hline Goat anti-mouse $\operatorname{lgG}$ & $1: 250$ & Cy3 & 1 \\
Goat anti-rabbit $\operatorname{lgG}$ & $1: 500$ & Cy3 & 1 \\
Donkey anti-goat lgG & $1: 500$ & Cy3 & 2 \\
Rabbit anti-goat lgG & $1: 500$ & Cy5 & 2 \\
\hline
\end{tabular}

Sources: 1, Jackson ImmunoResearch (West Grove, PA); 2, Chemicon.

mented with glial-derived neurotrophic factor $(20 \mathrm{ng} / \mathrm{ml}$; Upstate Biotechnology, Lake Placid, NY), ciliary neurotrophic factor (10 ng/ml; Upstate Biotechnology), and forskolin (50 $\mu \mathrm{M}$; Sigma; for fibroblast cocultures only) to aid in cell survival (Wichterle et al., 2002; MacDonald et al., 2003). A delay of $24 \mathrm{hr}$ before administration of these factors was required because earlier application of neurotrophic factors inhibited plating of ES cells.

\section{Immunohistochemistry}

Cells were fixed for $1 \mathrm{hr}$ in a 3.7\% formaldehyde (Fisher Scientific, Houston, TX) solution. Immunohistochemical labeling techniques were performed using antibodies against choline acetyltransferase (ChAT), microtubule-associated protein 2 (MAP2), and vesicular acetylcholine transporter (VAChT) (Table 1). To reduce background staining, tissue was treated overnight with $10 \%$ blocking serum. All primary antibodies were applied overnight in $10 \%$ blocking serum and $\mathrm{PBS}$ at $4^{\circ} \mathrm{C}$. Cells were then rinsed for $30 \mathrm{~min}$ in PBS and the secondary antibody (Table 2) was administered in $10 \%$ blocking serum for $2 \mathrm{hr}$ at $4^{\circ} \mathrm{C}$. Rhodamineconjugated $\alpha$-bungarotoxin (1:100; Molecular Probes, Eugene, OR), used to label acetylcholine receptors, was applied either in combination with secondary antibodies or alone during an additional $2 \mathrm{hr}$ incubation step. After $30 \mathrm{~min}$ of PBS rinsing, cells were coverslipped with mounting medium (Sigma). Images were captured using either a digital camera (Nikon Coolpix 4500; Nikon, Mississauga, Ontario, Canada) mounted on a fluorescence microscope (Leica DMLFS; Leica, Richmond Hill, Ontario, Canada) or via a laser-scanning confocal microscope (Zeiss LSM 510; Zeiss, Thornwood, NY). Orthogonal confocal images were rendered via Zeiss LSM Image Browser software.

\section{Electrophysiology}

Whole-cell patch-clamp recordings. Whole-cell patch-clamp recording techniques were used to study the intrinsic properties of ES cell-derived MNs in culture. Experiments were performed in a recording chamber that was perfused continuously with oxygenated artificial CSF (aCSF) at room temperature $(\mathrm{RT})\left(22-24^{\circ} \mathrm{C}\right)$. eGFP epifluorescence was always used to identify ES cell-derived MNs before recordings (see Fig. 3D). Whole-cell patch-clamp recordings were made from cells visualized with infrared differential interference contrast microscopy (see Fig. 3C,E) using a Leica DMLFSA upright microscope. Patch electrodes (resistance 4.0-5.0 M $\Omega$ ) were pulled on a Sutter P-87 puller (Sutter Instrument Company, Novato, CA) from $1.5 \mathrm{~mm}$ outer diameter filamented borosilicate glass (World Precision Instruments, Sarasota, FL). Signals recorded using whole-cell patch-clamp techniques were amplified and filtered (4 kHz low-pass Bessel filter) using a MultiClamp 700A amplifier (Axon Instruments, Union City, CA). Amplified signals were acquired at $10 \mathrm{kHz}$ using a Digidata 1322A analog-to-digital (A/D) board and pClamp 8 or 9 software (Axon Instruments). Series resistance, whole-cell capacitance $\left(C_{\mathrm{m}}\right)$, and input resistance $\left(R_{\mathrm{N}}\right)$ values were calculated using pClamp 8 or 9 software. An on-line P4 leak subtraction protocol (Heinemann, 1995) was used for all recordings of voltage-activated currents. All voltage and current-clamp protocols are described in Results. Signals were analyzed off-line using Clampfit 8 or 9 software (Axon Instru- 
ments). Differences between means were compared using Student's $t$ test. Values of $p<0.05$ were considered significant.

Intracellular recordings of muscle fibers. Sharp electrode recording techniques were used to measure activity of C2C12 muscle cells cocultured with ES cells. Experiments were again performed in a recording chamber perfused with oxygenated aCSF at RT. Electrodes (20-40 M $\Omega$ ) were pulled and filled with $3 \mathrm{~m}$ $\mathrm{KCl}$. Single muscle cells surrounding the RAHh-Ag-treated ES cells were visualized using a stereomicroscope and impaled. Only those cells with stable resting membrane potentials $\left(V_{\mathrm{m}}\right)$ of between -50 and $-60 \mathrm{mV}$ were included in the analysis. Postsynaptic endplate potentials (EPPs) were amplified via an intracellular amplifier (World Precision Instruments) coupled to a differential amplifier (Dagan, Minneapolis, $\mathrm{MN}$ ) and acquired at $10 \mathrm{kHz}$ using a Digidata 1322A A/D board and Axoscope software (Axon Instruments). Signals were analyzed off-line using the Mini Analysis Program (Jaejin Software, Leonia, NJ).

Solutions and drugs. The aCSF used in all electrophysiological experiments (except those investigating voltage-activated $\mathrm{Ca}^{2+}$ currents) contained (in mM): $127 \mathrm{NaCl}, 3 \mathrm{KCl}, 2 \mathrm{CaCl}_{2}, 1$ $\mathrm{MgSO}_{4}, 26 \mathrm{NaHCO}_{3}, 1.25 \mathrm{NaH}_{2} \mathrm{PO}_{4}, 10$ D-glucose (equilibrated with $95 \% \mathrm{O}_{2}$ and $5 \%$ $\mathrm{CO}_{2}$ at RT, pH 7.45; osmolarity, $\sim 310 \mathrm{mOsm}$ ). The standard pipette solution for whole-cell patch-clamp recordings contained (in $\mathrm{mm}$ ): 140 potassium methane-sulfonate, $10 \mathrm{NaCl}, 1$ $\mathrm{CaCl}_{2}, 10$ HEPES, 0.2 EGTA, 3 ATP-Mg, 0.4 GTP, pH 7.2-7.3 (adjusted with $\mathrm{KOH}$; osmolarity adjusted to $\sim 300 \mathrm{mOsm}$ with sucrose).

For experiments investigating voltageactivated $\mathrm{Ca}^{2+}$ currents, external and pipette solutions were designed to eliminate $\mathrm{Na}^{+}$and $\mathrm{K}^{+}$currents (Carlin et al., 2000a). The external solution contained (in mм): $115 \mathrm{NaCl}, 3 \mathrm{KCl}$, 30 TEA-Cl, 10 HEPES, $1 \mathrm{MgCl}_{2}, 2 \mathrm{CaCl}_{2}, 10$ D-glucose, 4 4-AP (gassed with $100 \% \mathrm{O}_{2}, \mathrm{pH}$ 7.35, adjusted with $\mathrm{NaOH}$; osmolarity, $\sim 305$ $\mathrm{mOsm}$ ). The pipette solution contained (in $\mathrm{mm}$ ): 100 Cs-methane-sulfonate, 30 TEA-Cl, $10 \mathrm{NaCl}, 1 \mathrm{CaCl}_{2}, 10$ HEPES, 1 EGTA, 3 ATP$\mathrm{Mg}, 0.4$ GTP, pH 7.2-7.3 (adjusted with $\mathrm{KOH}$; osmolarity adjusted to $\sim 295$ mOsm with sucrose).

All drugs were made up as concentrated stock solutions and stored in single-use vials (to eliminate freeze-thaw cycles) at $-20^{\circ} \mathrm{C}$. Final concentrations were achieved by diluting stock solutions in aCSF. Stock solutions of apamin, TTX, 4-AP, GABA, and glycine were made up in distilled water. Stock solutions of FPL-64176 and nifedipine were made up in ethanol (final concentration of ethanol, $0.2 \%)$. Stock solutions of glutamate were made up in $0.1 \mathrm{~m}$ $\mathrm{NaOH}$. Drug application was via addition to the perfusate.

\section{Results}

Differentiation of MNs from ES cells

Putative MNs were derived from HBG3 ES cells as described previously (Wichterle et al., 2002). Under our experimental conditions, cells within EBs began to express eGFP $\sim 24 \mathrm{hr}$ after RA
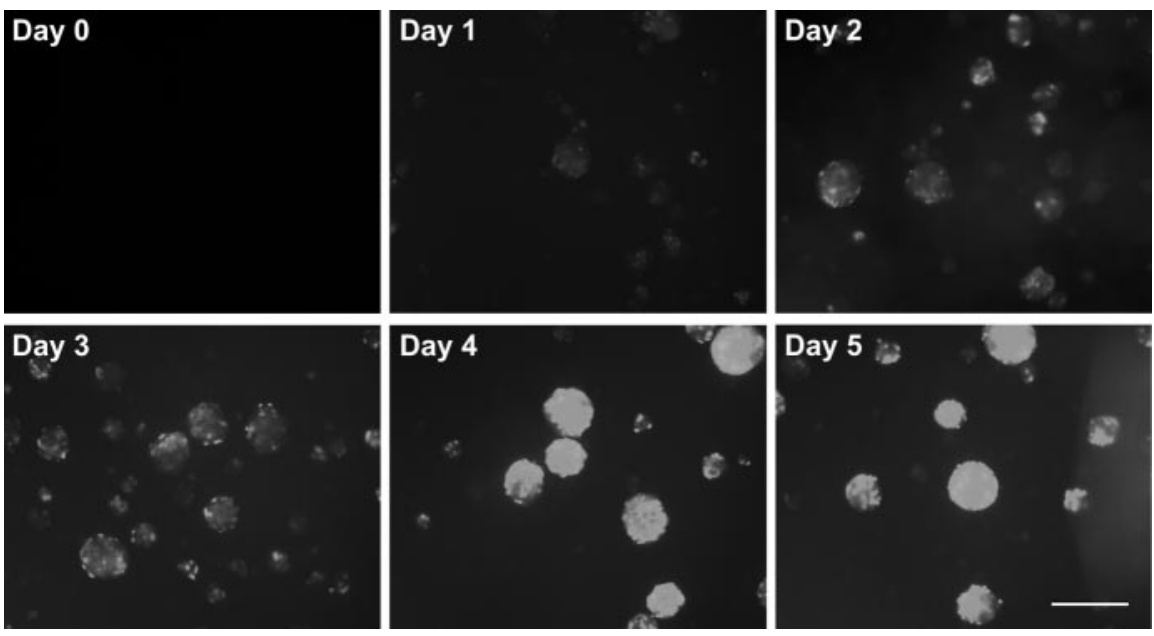

Figure 1. Embryoid bodies containing HBG3 ES cells express eGFP after treatment with RA and Hh-Ag1.3. ES cells suspended in DFK10 medium were treated with RA $(1 \mu \mathrm{M})$ and $\mathrm{Hh}-\mathrm{Ag} 1.3(1 \mu \mathrm{M})$ at day 0 to direct differentiation toward an MN phenotype. $\mathrm{Hb}$ upregulation was verified by eGFP expression under fluorescence microscopy. At $5 \mathrm{~d}$ in culture, the ES cell aggregates reached maximum size, evidenced under phase-contrast microscopy, and maximum eGFP expression. Scale bar, $200 \mu \mathrm{m}$.
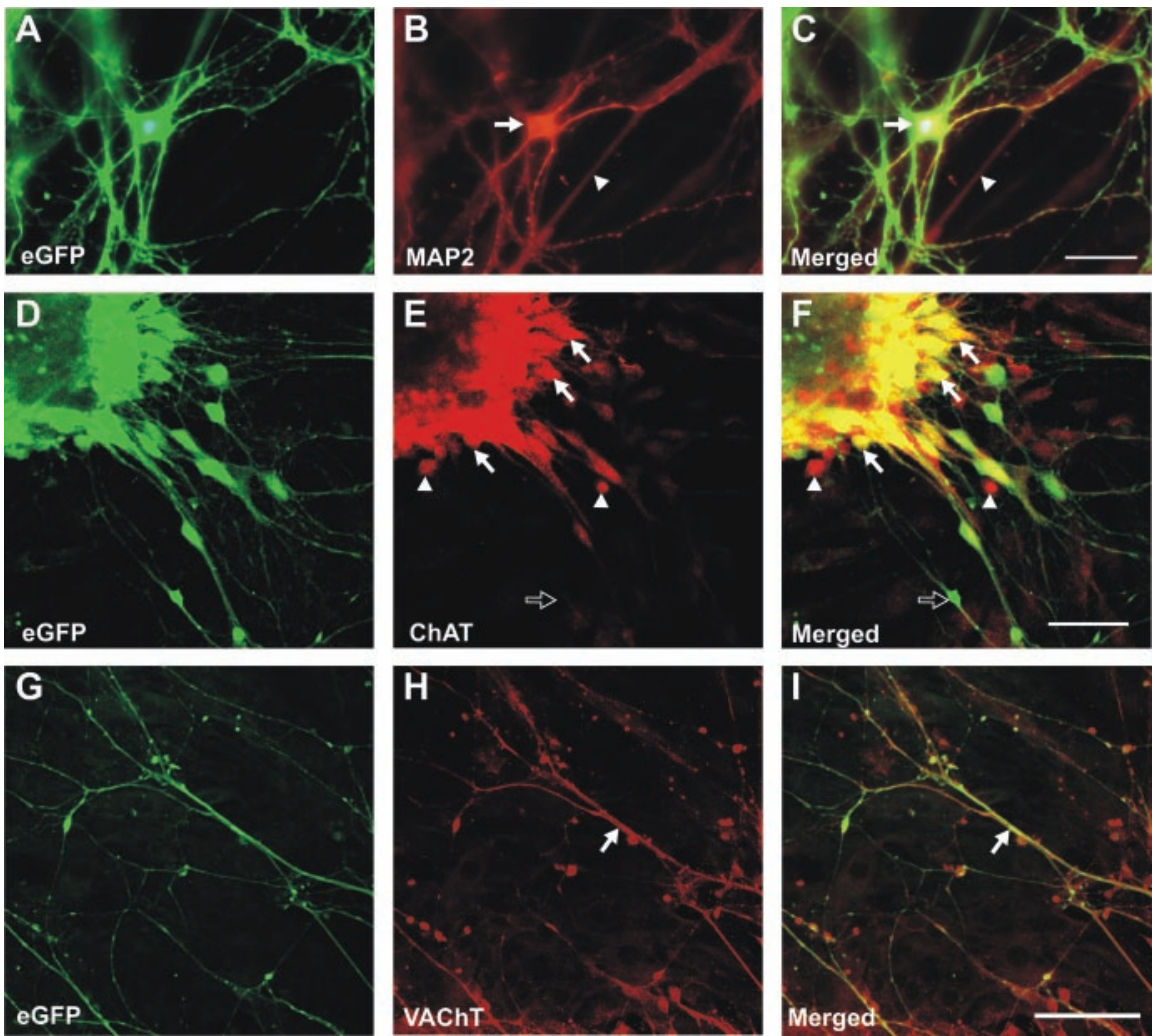

Figure 2. RA-Hh-Ag-treated ES cells express neuronal and cholinergic markers. Fluorescent image of RA-Hh-Ag1.3-treated ES cells shows that they extend long eGFP ${ }^{+}$neurites when cocultured on $\mathrm{C} 2 \mathrm{C} 12$ myotubes $(A, D, G)$. Many eGFP ${ }^{+}$ES cells expressed the neuronal marker MAP2 ( $B, C$, arrow). 0 ccasionally eGFP ${ }^{-}, M_{A P 2}{ }^{+}$neurites were seen $(B, C$, arrowhead). After 3 d in coculture, the majority of the eGFP ${ }^{+}$cells expressed $C h A T(E, F$, arrows), and the neurites expressed VAChT $(H, I$, arrow). A small proportion of $\mathrm{ChAT}^{+}$cells were eGFP ${ }^{-}\left(E, F\right.$, arrowheads) and some eGFP ${ }^{+}$cells were ChAT ${ }^{-}(E, F$, open arrows). Note the dense clustering of eGFP ${ }^{+}, \mathrm{ChAT}^{+}$neurons at the edge of the embryoid body ( $D-F$, top left). Together, these results indicate that most treated $\mathrm{ES}$ cells developed a cholinergic phenotype. $D-I$, Obtained using confocal microscopy $(D-F$, projection thickness $=9.9 \mu \mathrm{m} ; G-I$, projection thickness $=13.3 \mu \mathrm{m})$. Scale bars: $A-C, 30 \mu \mathrm{m} ; D-F, 50 \mu \mathrm{m} ; G-I, 100 \mu \mathrm{m}$.

and Hh-Ag1.3 were added to the culture medium (Fig. 1). The number of eGFP ${ }^{+}$cells in EBs increased until day 4 (Fig. 1), as described by Wichterle et al. (2002).

Five days after the onset of RA-Hh-Ag treatment, EBs were 

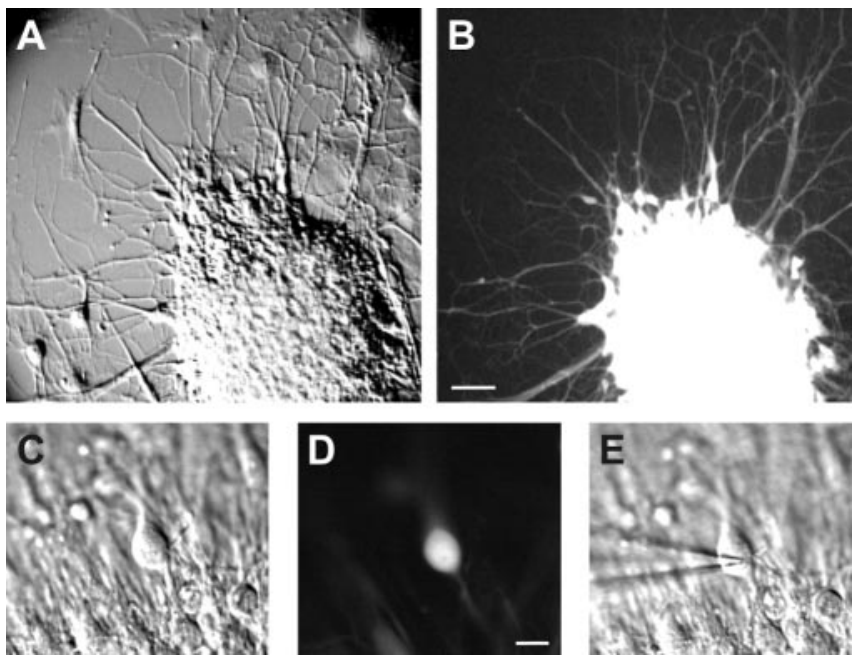

Figure 3. ES cell-derived MNs were identified by eGFP labeling and patched under infrareddifferential interference contrast (IR-DIC) microsopy. Low-magnification (10X) image of an embryoid body visualized under IR-DIC microscopy $(A)$ and under epifluorescence $(B)$ shows eGFP labeling of ES cell-derived MNs. High magnification (40 $X$ ) image of an ES cell-derived MN visualized under IR-DIC microscopy $(C$ and under epifluorescence $(D)$ confirms eGFP labeling before attaching a whole-cell patch-clamp recording electrode (E). Scale bars: $B, 50 \mu \mathrm{m} ; D, 10 \mu \mathrm{m}$.

Table 3. Development of passive membrane properties in ES cell-derived MNs

\begin{tabular}{llcl}
\hline Days after plating in coculture & $C_{\mathrm{m}}(\mathrm{pF})$ & $R_{\mathrm{N}}(\mathrm{M} \Omega)$ & $V_{\mathrm{m}}(\mathrm{mV})$ \\
\hline 1 & $16.6 \pm 1.0(4)$ & $1088 \pm 160(4)$ & $-35 \pm 6(4)$ \\
2 & $30.7 \pm 2.7(13)^{a}$ & $736 \pm 80(13)$ & $-43 \pm 2(13)$ \\
3 & $30.4 \pm 2.0(18)$ & $520 \pm 35(18)^{a}$ & $-47 \pm 2(18)$ \\
4 & $31.7 \pm 1.7(25)$ & $627 \pm 62(25)$ & $-54 \pm 2(25)^{a}$ \\
\hline
\end{tabular}

Values are mean $\pm \mathrm{SE}$; number of cells in parentheses.

${ }^{a}$ Significantly different from data at previous time point; Student's $t$ test $(p<0.05)$.

plated on a monolayer of differentiated C2C12 myotubes. One day after plating, $\mathrm{eGFP}^{+}$cells extended long neurites across the myotubes, and all expressed the neuronal marker MAP2 ( $n=5$ cultures) (Caceres et al., 1984; Papasozomenos et al., 1985). Approximately half of the MAP2-immunopositive neurites within and in close proximity to the EBs were $\mathrm{eGFP}^{-}$(Fig. $2 A-C$, arrowheads). Many of these MAP2-immunopositive eGFP ${ }^{-}$cells had short neurites and were presumably ventral interneurons (Wichterle et al., 2002).

Three days after plating $\left(n=9\right.$ cultures), $>95 \%$ of $\mathrm{eGFP}^{+}$ neurons (Fig. 2D) within EBs, as well as those that had migrated onto the surrounding myotubes, expressed ChAT (Fig. $2 E$, arrows), indicating that they had acquired a cholinergic transmitter phenotype. This is similar to the ChAT expression seen in these cells after differentiation and dissociation (Wichterle et al., 2002). A low proportion $(<10 \%)$ of the ChAT-immunopositive cells were $\mathrm{eGFP}^{-}$(Fig. 2E, arrowheads, $F$ ), suggesting that ES cells also generate cholinergic interneurons or $\mathrm{eGFP}^{-} \mathrm{MNs}$.

During development, synaptic proteins are distributed in the axons and synaptic terminals of chick (Dahm and Landmesser, 1991) and mouse (Lupa and Hall, 1989) MNs. Consistent with these in vivo studies, the neurites (Fig. $2 \mathrm{H}, \mathrm{I}$, arrows) of eGFP ${ }^{+}$ cells expressed VAChT ( $n=11$ cultures). Together, these results support the findings of Wichterle et al. (2002) that, in the presence of RA-Hh-Ag, HBG3 ES cells differentiate into neurons that have many of the molecular characteristics of MNs.

\section{Passive properties of ES cell-derived MNs}

To investigate the degree to which ES cell-derived MNs express the passive physiological properties characteristic of MNs, whole- cell patch-clamp recordings were made from $\mathrm{eGFP}^{+}$neurons (Fig. 3). During late embryonic development [from E16 to postnatal day $0(\mathrm{P} 0)]$, the resting membrane potential of rat phrenic MNs hyperpolarizes (by $\sim 10 \mathrm{mV}$ ) and the input resistance decreases (by $\sim 67 \%$ ) (Martin-Caraballo and Greer, 1999). The passive membrane properties of ES cell-derived MNs changed similarly with time in culture, reaching relatively steady states 3-4 d after plating (Table 3 ). The resting membrane potential hyperpolarized from $-35 \pm 6 \mathrm{mV}$ at day 1 to a steady state of $-54 \pm 2 \mathrm{mV}$ by day 4 . There was also a decrease in input resistance over the first $3 \mathrm{~d}$ from $1088 \pm 160$ to $520 \pm 35 \mathrm{M} \Omega$. In addition, using whole-cell capacitance as an indicator of cell surface area, clearly there was rapid growth in ES cell-derived MNs over the first $2 \mathrm{~d}$, during which time whole-cell capacitance increased from $16.6 \pm$ 1.0 to $30.7 \pm 2.7 \mathrm{pF}$. All subsequent analysis of membrane currents was performed on ES cell-derived MNs that had been cultured for 3-7 d after establishment of coculture. The average passive membrane properties for cells in the 3-7 $\mathrm{d}$ group were as follows: $C_{\mathrm{m}}, 31.3 \pm 1.1 \mathrm{pF} ; R_{\mathrm{N}}, 570 \pm 28 \mathrm{M} \Omega$; and $V_{\mathrm{m}},-53 \pm 1 \mathrm{mV}$ $(n=71)$. These values are comparable with E18 rat phrenic MNs $\left(R_{\mathrm{N}}=551 ; V_{\mathrm{m}}=-57.4\right)$ (Martin-Caraballo and Greer, 1999) and $\mathrm{P} 1-\mathrm{P} 3$ rat lumbar MNs $\left(C_{\mathrm{m}}=33.2 ; R_{\mathrm{N}}=734\right)$ (Gao and ZiskindConhaim, 1998).

\section{Neurotransmitter effects on ES cell-derived MNs}

Functional GABA and glycine receptors are present on embryonic MNs as early as E17 (Wu et al., 1992; Gao and ZiskindConhaim, 1995). Responses to GABA and glycine receptor activation in MNs involve a chloride conductance, which mediates membrane depolarization during embryonic and early postnatal stages (Wu et al., 1992; Gao and Ziskind-Conhaim, 1995) and membrane hyperpolarization at mature stages (Curtis et al., 1968; Werman et al., 1968). This developmental change likely reflects a change in the chloride equilibrium potential after upregulation of a $\mathrm{K}^{+} / \mathrm{Cl}^{-}$cotransporter (Stein et al., 2004).

To determine whether GABA and glycine receptors are present on ES cell-derived MNs, we assayed the sensitivity of these neurons to bath application of GABA and glycine during voltage-clamp recordings. Bath application is useful for the determination of steady-state currents mediated by these receptors; however, peak currents desensitize and therefore may be underestimated.

Applications of GABA $(100 \mu \mathrm{M})$ to ES cell-derived MNs induced inward currents of $-50 \pm 5 \mathrm{pA}(n=7)$ in $\mathrm{eGFP}^{+}$neurons held at $-60 \mathrm{mV}(n=7)$ (Fig. $4 A i)$. Similar to those seen in (embryonic) MNs (Gao and Ziskind-Conhaim, 1995), GABAinduced currents were mediated by an increase in conductance $(465 \pm 168 \% ; n=4)$ and had one inward component that rapidly desensitized and another that persisted for several minutes after washout of the drug began. Drug applications performed in the presence of TTX $(0.5 \mu \mathrm{M})$ were used to analyze the currentvoltage relationship of induced currents. The control data were subtracted from those obtained during drug applications to obtain the $I-V$ curves illustrated. The reversal potential for these GABA-induced currents was found to be $-57 \pm 3 \mathrm{mV}(n=4)$ (Fig. 4Aii).

Glycine $(100 \mu \mathrm{M})$ applications also induced inward currents, but they were much smaller $(-9 \pm 2 \mathrm{pA}$ at $-60 \mathrm{mV} ; n=6)$ (Fig. $4 \mathrm{Bi}$ ) than those activated by GABA. Glycine-induced currents were also associated with increased conductance $(62 \pm 17 \%$; $n=$ $6)$ and had reversal potentials similar to GABA-mediated currents $(-56 \pm 2 \mathrm{mV} ; n=6)$ (Fig. $4 \mathrm{Bii})$. The reversal potentials of both glycine and GABA-mediated currents were close to the $\mathrm{Cl}^{-}$ 
equilibrium potential $(-62 \mathrm{mV})$ calculated for our combination of intracellular and extracellular solutions.

As in other neurons, excitation of embryonic and postnatal MNs is mediated by glutamate binding to both non-NMDA and NMDA receptors (Jiang et al., 1990). Glutamate $(100 \mu \mathrm{M})$ applications were used to identify functional glutamatergic receptors in ES cell-derived MNs. Glutamate-induced inward currents averaged $-90 \pm 19 \mathrm{pA}$ at $-60 \mathrm{mV}(n=15)$ (Fig. 4Ci). Glutamate applications performed in the presence of TTX $(0.5 \mu \mathrm{M})$ and TEA ( $30 \mathrm{mM})$ were used for analysis of current-voltage relationships. Using methods as described above for GABA applications, this analysis demonstrated that glutamate-induced currents were associated with an increase in conductance $(41 \pm 17 \% ; n=5)$ and had reversal potentials of $3 \pm 5 \mathrm{mV}(n=5)$ (Fig. 4 Cii), in keeping with the expression of a mixed cationic current.

To examine whether ES cell-derived MNs receive functional synaptic input, glutamate application was used to excite neurons. In ES cell-derived MNs cocultured for $>5 \mathrm{~d}$, application of glutamate induced EPSCs $(n=3)$ (Fig. 4Ciii). These events were not seen after TTX application and were not seen in ES cell-derived MNs cocultured for $<6 \mathrm{~d}$. This demonstrates that synapses within the EBs develop after $5 \mathrm{~d}$ in coculture.

\section{Ion channels in ES cell-derived MNs}

To produce trains of action potentials necessary for muscle contractions, MNs require several fundamental conductances. These include the voltage-dependent fastinactivating sodium channel, which gives rise to action potential depolarization, and the voltage-dependent noninactivating potassium channel (delayed rectifier) responsible for action potential repolarization. In addition, MNs, like many other types of neurons, have a transient inactivating potassium channel $\left(I_{\mathrm{A}}\right)$ (McLarnon, 1995) and a range of voltage-activated $\mathrm{Ca}^{2+}$ channels (Carlin et al., 2000a). Voltage-clamp protocols were used to study these voltage-activated $\mathrm{Na}^{+}, \mathrm{K}^{+}$, and $\mathrm{Ca}^{2+}$ conductances in ES cellderived MNs.

Voltage steps (50 msec duration) from a holding potential of $-60 \mathrm{mV}$ to a range of test potentials between -100 and $+40 \mathrm{mV}$ (10 mV increments) demonstrated fast-inactivating $\mathrm{Na}^{+}$currents. These steps activated large $(-3750 \pm 304 \mathrm{pA} ; n=35)$ inward currents that inactivated rapidly and were sensitive to TTX (0.5 $\mu \mathrm{M} ; n=25)$ (Fig. $5 A)$. Current-voltage relationships for these currents showed that they activated near $-40 \mathrm{mV}$ and peaked at $-20 \mathrm{mV}$ (Fig. 5Aii).

In the presence of TTX $(0.5 \mu \mathrm{M})$ to block fast-inactivating $\mathrm{Na}^{+}$currents, voltage steps (250 msec duration) from a holding potential of $-40 \mathrm{mV}$ to test potentials between -30 and $+50 \mathrm{mV}$
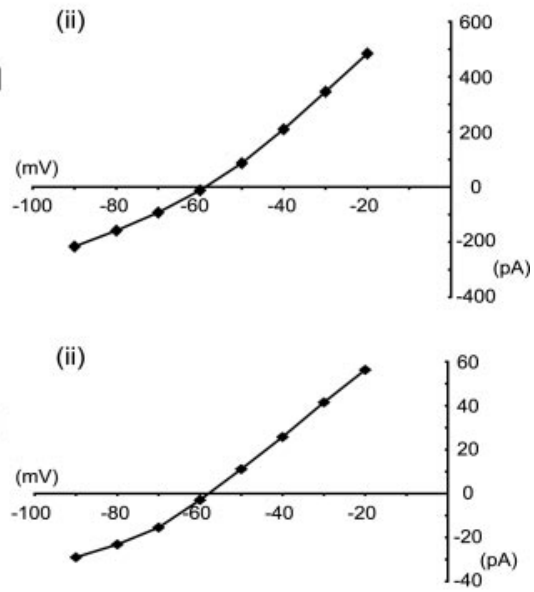

(ii)

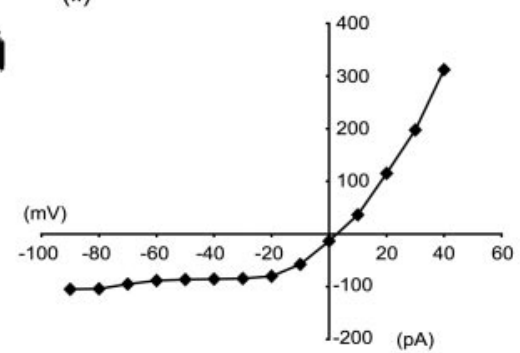

(pA)

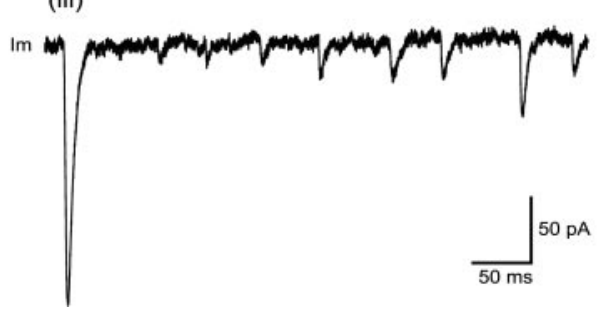

Figure 4. ES cell-derived MNs express functional neurotransmitter receptors. Voltage-clamp recordings of membrane current $\left(I_{\mathrm{m}}\right)$ during application of GABA (100 $\left.\mu \mathrm{M}\right)(A i)$, glycine (GLY; $\left.100 \mu \mathrm{M}\right)(B i)$, and glutamate (GLUT; $\left.100 \mu \mathrm{M}\right)$ (Ci, Ciii). Currentvoltage relationships for GABA-, glycine-, and glutamate-induced currents are shown in Aiil, Bii, and Cii, respectively. Voltage steps increments) were performed before and during drug responses. Steady-state currents (the last $20 \mathrm{msec}$ of pulses) were used to generate current-voltage plots under control conditions and during drug responses after steady state was reached. Dotted lines indicate membrane current under control conditions. A holding potential of $-60 \mathrm{mV}$ was used during all drug applications. After glutamate application in cells in coculture conditions for $>5 \mathrm{~d}$, EPSCS were recorded in ES cell-derived MNs (Ciii). Note: delayed responses to drug applications reflect the time taken for the drug to wash into the recording chamber (typically $1 \mathrm{~min}$ ).

(10 $\mathrm{mV}$ increments) were used to study persistent (delayed rectifier-like) $\mathrm{K}^{+}$currents in ES cell-derived MNs. These voltage steps activated persistent outward currents (Fig. 5Bi). Currentvoltage relationships for these currents (generated using the last $20 \mathrm{msec}$ of the voltage steps) indicated that they activated near $-20 \mathrm{mV}$, increased in magnitude with more positive voltage steps $(n=24)$ (Fig. 5 Biii), and were almost completely blocked by externally applied TEA ( $30 \mathrm{~mm} ; n=3$ ) (Fig. 5Bii,Biii).

Similar protocols using a holding potential of $-80 \mathrm{mV}$ demonstrated that ES cell-derived MNs also possess a transient $\left(I_{\mathrm{A}^{-}}\right.$like) outward current (Fig. 5Ci). This current could be isolated by subtracting responses to voltage steps made using a holding potential of $-40 \mathrm{mV}$ (at which only the persistent outward current was activated) from responses to the same steps made using a holding potential of $-80 \mathrm{mV}$ (at which both transient and persistent currents were activated) (Gao and Ziskind-Conhaim, 1998; Alessandri-Haber et al., 2002). The resulting traces revealed 
A (i) Control

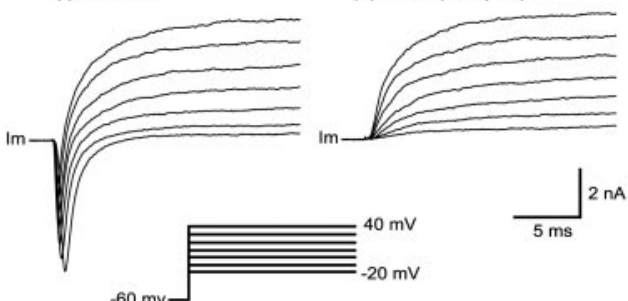

B

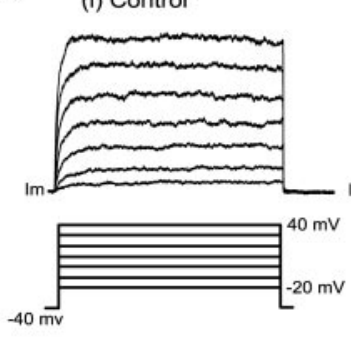

C (i) $\mathrm{Vh}=-80 \mathrm{mV}$
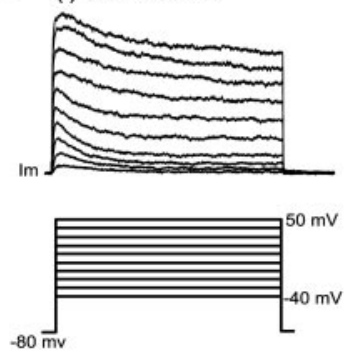

(iv) Subtracted current $\left(\mathrm{I}_{\mathrm{A}}\right)$
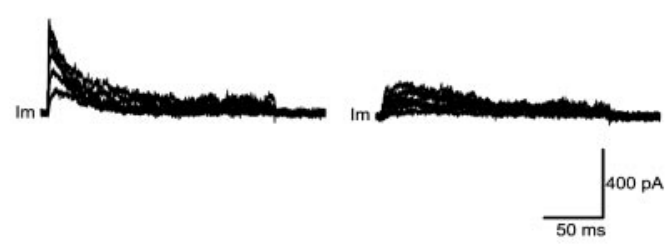

D (i) $\mathrm{Vh}=-60$

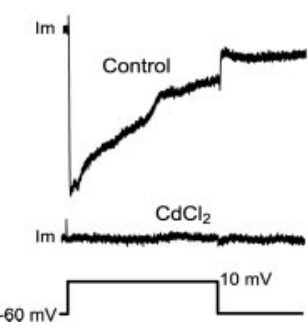

(ii) $\mathrm{Vh}=-80$

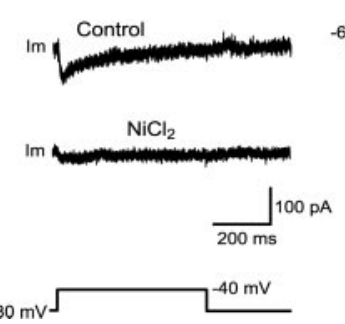

(ii) $\mathrm{Vh}=-40 \mathrm{mV}$

(v) 4-AP (4 mM) (iii)

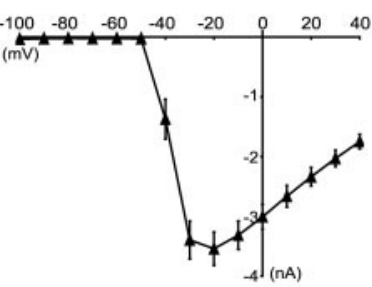

(iii)
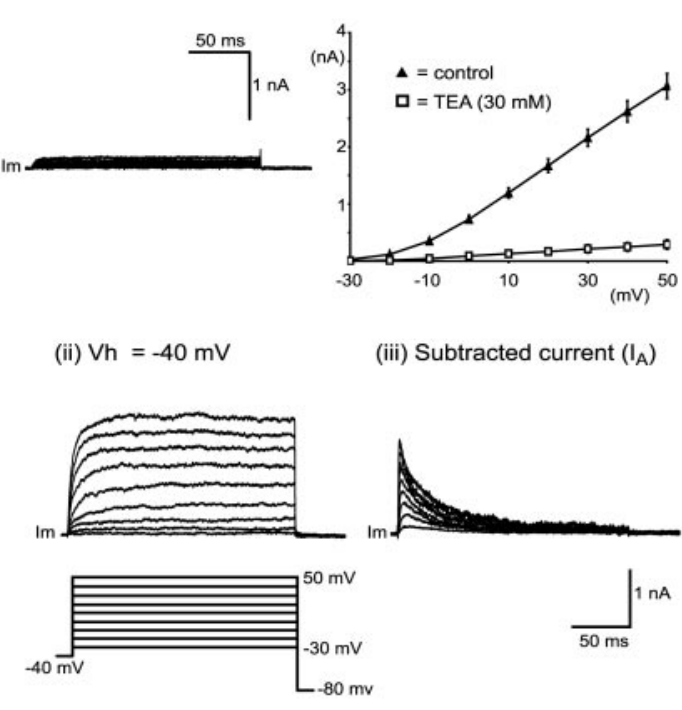

(vi)

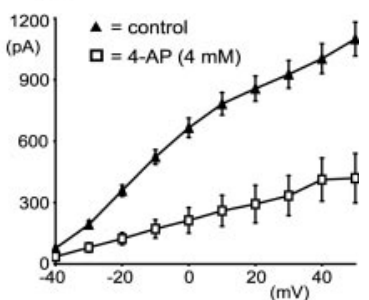

(iii)

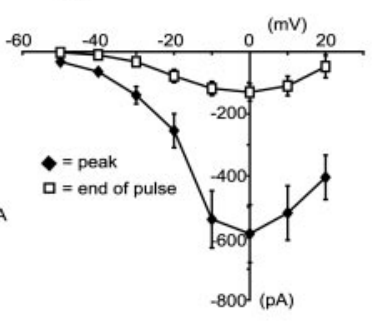

Figure 5. ES cell-derived MNs express voltage-activated $\mathrm{Na}^{+}, \mathrm{K}^{+}$, and $\mathrm{Ca}^{2+}$ currents. $A$, Fast-inactivating $\mathrm{Na}^{+}$currents. Voltage-clamp recordings of membrane current $\left(I_{\mathrm{m}}\right)$ in response to depolarizing voltage steps demonstrating fast-inactivating outward currents $(i)$ that are sensitive to TTX $(0.5 \mathrm{~mm})$ (ii). Voltage-current relationships for fast-inactivating currents are shown in iii $(n=35)$. B, Delayed rectifier $\mathrm{K}^{+}$currents $\left(I_{\mathrm{K}}\right)$. Voltage-clamp recordings show persistent outward currents $(i)$ activated by depolarizing steps from a holding potential of $-40 \mathrm{mV}$ that are sensitive to TEA ( $30 \mathrm{~mm}$ ) (ii). Current-voltage relationships for these persistent outward currents are shown in iii $(n=24)$, along with the blocking effects of TEA $(n=3)$. C, Transient $\mathrm{K}^{+}$ currents $\left(I_{A}\right)$. Voltage-clamp recordings of outward currents activated by depolarizing steps from $-80 \mathrm{mV}$ (i) or $-40 \mathrm{mV}$ (ii). The subtraction of responses to steps from these two holding potentials revealed a transient current (iii) that required a holding potential of $-80 \mathrm{mV}$ for activation. This transient current (iv) was reduced by 4-AP ( $4 \mathrm{~mm}$ ) ( $v$ ). The current-voltage relationship for this transient current is shown in vi $(n=19)$, along with the blocking effects of 4-AP $(n=5)$. D, Voltage-activated Ca ${ }^{2+}$ currents. Voltage-clamp recordings after elimination of $\mathrm{Na}^{+}$and $\mathrm{K}^{+}$currents show inward currents activated by depolarizing steps from a holding potential of $-60 \mathrm{mV}$ (i) or $-80 \mathrm{mV}$ (ii). These currents are sensitive to cadmium and nickel, respectively. Current-voltage relationships for $\mathrm{Ca}^{2+}$ currents elicited from a holding potential of $-80 \mathrm{mV}$ are plotted in iii, using peak inward current (filled diamonds) or current averaged during the last 20 msec of voltage steps (open squares; $n=9$ ). a transient outward current that inactivated within $50 \mathrm{msec}$ (Fig. 5Ciii). This current was sensitive to the $I_{\mathrm{A}}$ channel blocker 4-AP ( $4 \mathrm{~mm} ; n=5$ ) (Fig. $5 \mathrm{Cv}, \mathrm{Cvi}$ ).

When $\mathrm{Na}^{+}$and $\mathrm{K}^{+}$currents were completely blocked with external TTX $(0.5 \mu \mathrm{M})$, external 4-AP (4 mM), external and internal TEA $(30 \mathrm{mM})$, and internal Cs $(100 \mathrm{~mm})$, depolarizing voltage steps (500 msec duration) from a holding potential of $-60 \mathrm{mV}$ to test potentials between -50 and $+20 \mathrm{mV}$ ( $10 \mathrm{mV}$ increments) elicited inward currents in ES cell-derived MNs $(n=9)$ (Fig. 5D). These currents were verified as voltage-activated $\mathrm{Ca}^{2+}$ currents by their complete block after application of the nonspecific voltage-activated $\mathrm{Ca}^{2+}$ channel blocker cadmium $(0.1 \mathrm{~mm} ; n=2)$ (Fig. 5Di). The current-voltage relationship for these currents demonstrated that they activated near $-40 \mathrm{mV}$, reaching maximum amplitude at $0 \mathrm{mV}$ (Fig. 5Diii) $(n=9)$. To investigate a lower threshold $\mathrm{Ca}^{2+}$ current, voltage steps from a holding potential of -80 to $-40 \mathrm{mV}$ were used (Fig. 5Dii) $(n=5)$ (Martin-Caraballo and Greer, 2001). These steps produced transient inward currents that were blocked by the selective T-type channel blocker nickel $(0.1 \mathrm{~mm} ; n=2)$ (Fig. 5Dii) (MartinCaraballo and Greer, 2001).

These findings show that ES cellderived MNs develop a range of voltageactivated channels, including fastinactivating sodium channels, delayed rectifier potassium channels, inactivating potassium channels $\left(I_{\mathrm{A}}\right)$, and voltageactivated $\mathrm{Ca}^{2+}$ channels.

\section{Firing properties of ES} cell-derived MNs

MNs are known to fire repetitively with a graded rate that increases in proportion to somatic current injection (Granit et al., 1963). The minimum and maximum firing rates and the slope of this frequencycurrent $(f-I)$ function vary for different classes of MNs (those innervating slowtwitch vs fast-twitch muscle). These properties are also state-dependent, in that they differ, for example, in anesthetized versus decerebrate animals and walking versus nonwalking states (Brownstone et al., 1992; Heckman et al., 2003).

The $f-I$ relation of ES cell-derived MNs was investigated using current-clamp techniques in which a series of current pulses $(1 \mathrm{sec})$ of increasing amplitude (2-10 pA steps) were injected. This protocol activated action potentials from the first day in coculture onward. During the first $2 \mathrm{~d}$ in coculture, only single action potentials could be induced $(n=18)$ (Fig. 
A

(i) 1 day

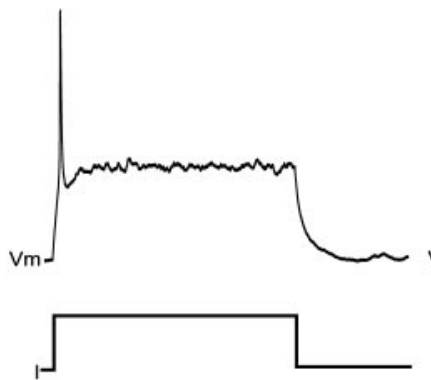

(ii) 4 days

B (i)
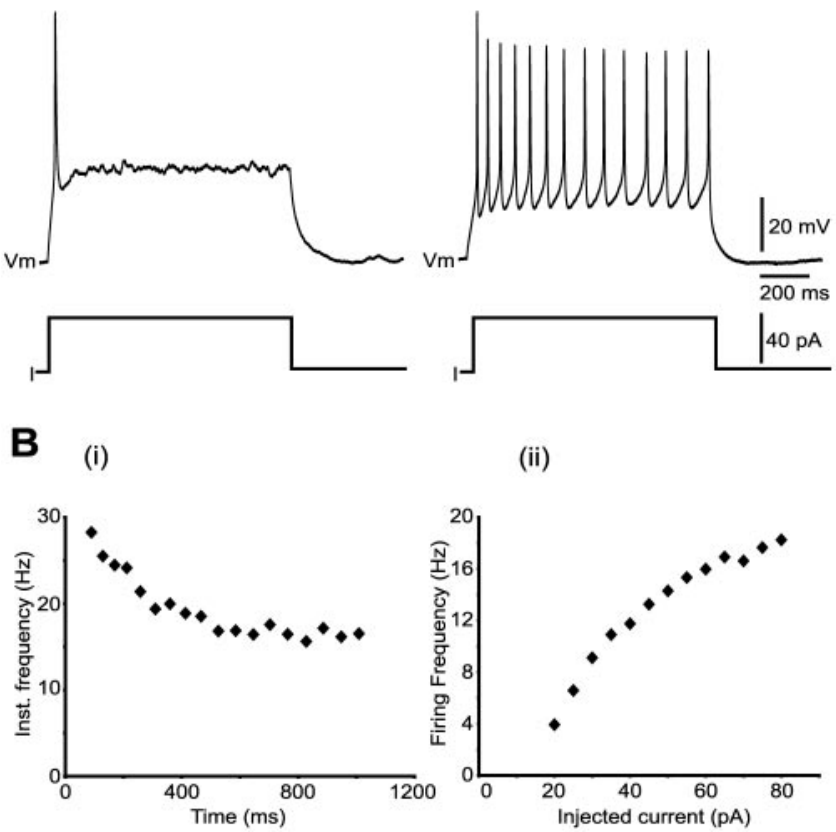

(ii)

C (i) Control

(ii) FPL-64176
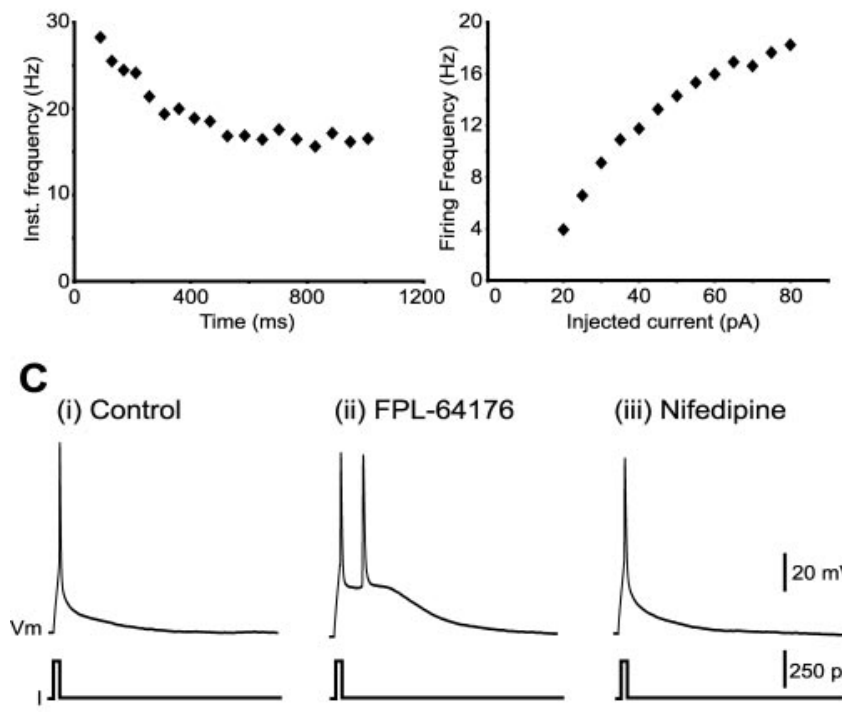

(iii) Nifedipine

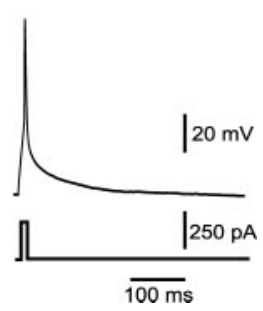

Figure 6. ES cell-derived MNs develop appropriate firing properties. A, Current-clamp recordings of membrane voltage $(V \mathrm{~m})$ in response to current $(I)$ injection (1 sec duration) in ES cell-derived MNs showing single action potentials $1 \mathrm{~d}$ after plating ( $i$ ) and repetitive firing $4 \mathrm{~d}$ after plating (ii). $B$, Plots of instantaneous firing frequency versus time during a single current pulse showing spike frequency adaptation $(i)$ and steady-state firing frequency versus injected current (ii). C, Responses to short (10 msec) current pulses in control showing a single action potential $(i)$ and in the presence of FPL-64176 $(10 \mu \mathrm{M})(i i)$, showing the induction of a long-lasting depolarization and action potential doublet, which was blocked by nifedipine $(20 \mu \mathrm{M})(i i i)$.

$6 A i)$. By the third day, repetitive trains of action potentials were elicited (Fig. 6Aii). This recapitulates the development of repetitive firing in lumbar spinal MNs in vivo (Gao and ZiskindConhaim, 1998). All subsequent current-clamp experiments were performed on cells that had been cultured for at least $3 \mathrm{~d}$ after plating in cocultures. In total, repetitive firing was observed in 52 of 61 cells tested at time points between 3 and $7 \mathrm{~d}$ after plating. During repetitive firing, spike frequency adaptation was observed as evidenced by instantaneous frequency versus time plots for single current steps (Fig. 6Bi). The minimum current required to elicit repetitive firing was $25 \pm 5 \mathrm{pA}(n=13)$, and the minimum firing frequency observed was $5.1 \pm 0.4 \mathrm{~Hz}(n=13)$. Graphs of steady-state firing frequency (averaged over the last $500 \mathrm{msec}$ of pulses) versus injected current showed that firing frequency increased with increased current injection (Fig. 6Bii). In cells that appeared to have been driven close to their maximum firing frequency, the fastest firing rates observed were $18.4 \pm 0.3$ $\mathrm{Hz}(n=9)$. Given that $f-I$ relationships were nonlinear, slopes could not be accurately determined.
The firing rate of adult cat MNs is regulated by apamin-sensitive $\mathrm{Ca}^{2+}$-dependent $\mathrm{K}^{+}$channels $\left(\mathrm{K}_{(\mathrm{Ca})}\right)$ that underlie the afterhyperpolarization (Baldissera and Gustafsson, 1971; Zhang and Krnjevic, 1987). Therefore, the role of $I_{\mathrm{K}(\mathrm{Ca})}$ in repetitive firing of differentiated ES cells was examined using the SK-type $\mathrm{K}_{(\mathrm{Ca})}$ channel blocker apamin (100 nM). Apamin had no effect on frequency-current relationships ( $n=6$; data not shown). Whether the lack of apaminsensitive $\mathrm{K}_{(\mathrm{Ca})}$ channels reflects a normal developmental process (Dutia and Johnston, 1998; Klocker et al., 2001) or results from our culture conditions is not clear.

$\mathrm{Ca}_{\mathrm{V}} 1$-type $\mathrm{Ca}^{2+}$ channels in MNs are important in the amplification of synaptic input, the production of plateau potentials (Heckman et al., 2003), and the generation of rhythmic motor activity (Hounsgaard and Kiehn, 1989; Jiang et al., 1999; Carlin et al., 2000b). To investigate whether these channels can produce sustained depolarizations in ES cell-derived MNs, we studied the effects of the $\mathrm{Ca}_{\mathrm{V}} 1$-type $\mathrm{Ca}^{2+}$ channel activator FPL-64176 (10 $\mu \mathrm{M})$ on $\mathrm{MN}$ firing. A brief depolarizing current pulse activated only single action potentials in the control condition (Fig. 6Ci). Application of FPL-64176 led to sustained depolarizations and sometimes action potential doublets $(n=8)$ (Fig. 6Cii). These effects were reversed by the $\mathrm{Ca}_{\mathrm{V}} 1$-type $\mathrm{Ca}^{2+}$ channel blocker nifedipine (20 $\mu \mathrm{M} ; n=3$ ) (Fig. 6Ciii). These findings demonstrate that $\mathrm{Ca}_{\mathrm{V}} 1$-type $\mathrm{Ca}^{2+}$ channels, which are critical for $\mathrm{MN}$ function, develop in ES cell-derived MNs.

\section{Functional connections between ES cell-derived MNs and muscle cells}

Using anatomical and electrophysiological analysis we investigated whether ES cell-derived MNs form functional connections with muscle fibers. As described above, these neurons express VAChT (Fig. $2 H$ ), which indicates that they contain at least some of the presynaptic machinery required to package acetylcholine into vesicles for its release at neuromuscular junctions (Gilmor et al., 1996). One day after coculturing with C2C12 myotubes (Fig. $7 \mathrm{Ai}$ ), acetylcholine receptor clustering occurred on myotubes immediately adjacent to the developing axons (Fig. 7Aii, arrow, Aiii), indicating that postsynaptic specializations developed in the cocultures ( $n=9$ cultures). In these culture conditions, such clustering was not seen on $\mathrm{C} 2 \mathrm{C} 12$ myotubes cultured in the absence of ES cells or at a distance from the axon-like processes (Fig. $7 B)$. Confocal imaging revealed colocalization of $\mathrm{eGFP}^{+}$axons and acetylcholine receptors (Fig. 7C). Because eGFP ${ }^{+}$axons grew on the surface of the $\mathrm{C} 2 \mathrm{C} 12$ myotubes, imaging in the $x-z$ orthogonal plane was used to confirm close apposition of $\mathrm{eGFP}^{+}$axons and acetylcholine receptors (Fig. 7C). Although acetylcholine receptor clustering occurred preferentially near eGFP ${ }^{+}$axons, clustering was not always clearly opposed to eGFP ${ }^{+}$axons. This parallels development in the chick (Dahm and Landmesser, 1991) and mouse (Lupa and Hall, 1989), in which receptor clustering first forms near but not always at the site of direct anatomical contact by motor axons. These results indicate that as early as $1 \mathrm{~d}$ in coculture, ES cell-derived MNs induce receptor clustering necessary for neuromuscular transmission.

Physiological assessment of synapse formation was performed using intracellular sharp electrode recordings from single $\mathrm{C} 2 \mathrm{C} 12$ myotubes $(n=4)$ or chick myotubes $(n=13)$. As early as $2 \mathrm{~d}$ after plating, numerous small (Fig. $8 A$, arrow) and some large (Fig. $8 A$, arrowhead) EPPs were recorded from C2C12 myotubes located adjacent to the EBs (frequency of occurrences plotted at the right). The amplitude and biphasic nature of the EPPs were similar to those reported for cocultures of mouse myotubes and a neuronal cell line (Chen et al., 2001). The reason for the biphasic 

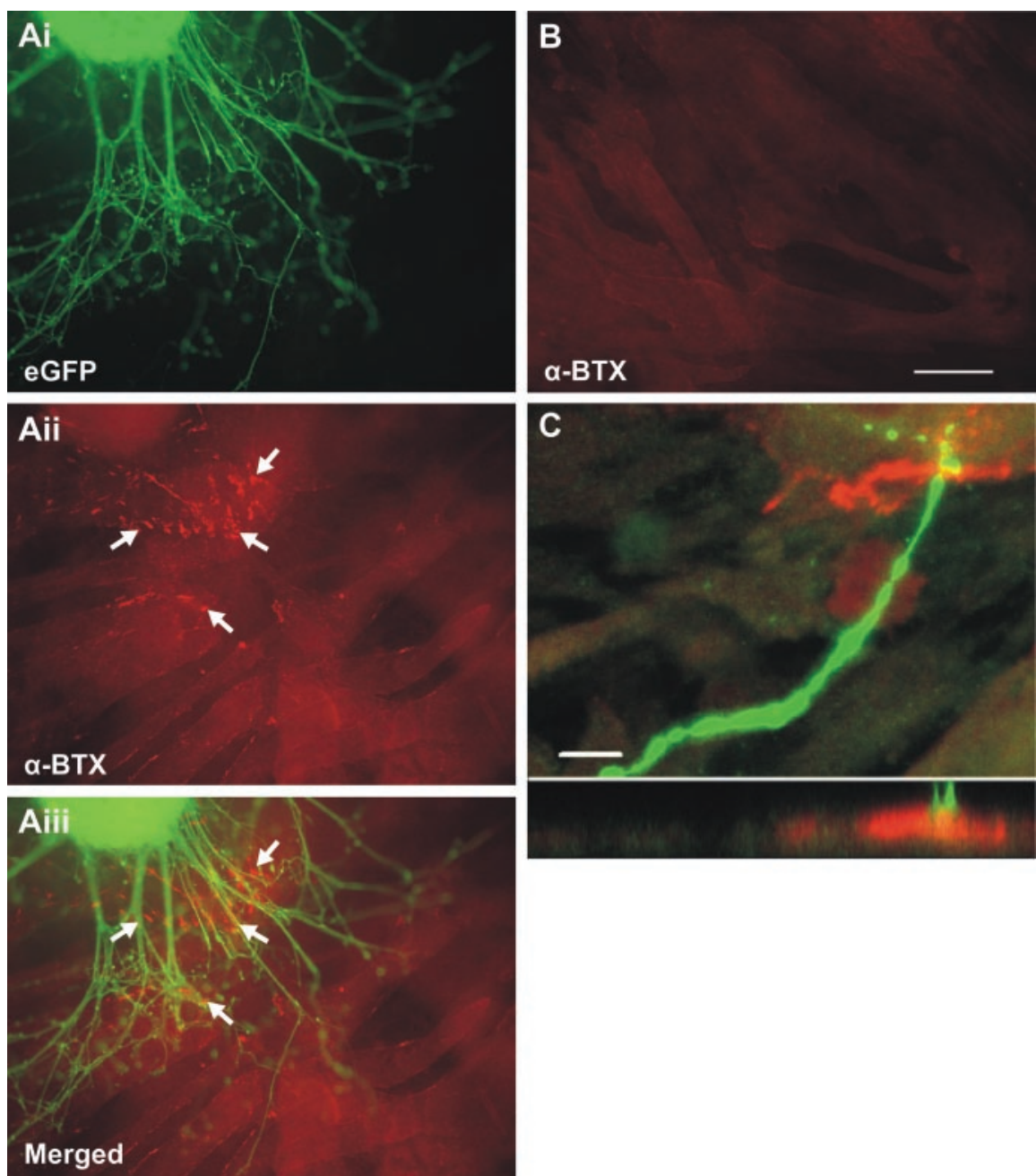

Figure 7. RA-Hh-Ag-treated ES cells induce acetylcholine receptor clustering on myotubes. Ai, Fluorescence image of eGFP ${ }^{+}$ RA-Hh-Ag1.3-treated ES cells after $2 \mathrm{~d}$ of coculture with C2C12 myotubes. Aii, $\alpha$-BTX staining revealed acetylcholine receptor clustering on $22 \mathrm{C} 12$ muscle fibers (Aii, arrows). Aiii, Merged image of Ai and Aii revealed acetylcholine receptor clustering only in close proximity to $\mathrm{eGF}^{+}$axons and cell bodies. $B$, Acetylcholine receptor clustering was absent on myotubes several millimeters away from the embryoid body. C, Confocal image depicting eGFP ${ }^{+}$axons colocalized with acetylcholine receptors (projection of 18 optical sections of $0.75 \mu \mathrm{m}$ each). Imaging in the $x-z$ orthogonal plane, in a line through the region of apparent colocalization, confirmed eGFP ${ }^{+}$terminals in close proximity to ACh receptors. Scale bars: $A, B, 100 \mu \mathrm{m} ; C, 10 \mu \mathrm{m}$.

nature of the EPP recordings is not immediately obvious. One possibility, however, is that because the recordings were not performed in the presence of paralytic agents, small contractile movements during the EPPs cause a leakage current around the glass electrode.

Given that ES cell-derived MNs express glutamate receptors (Fig. 4C) whereas the myotubes do not, bath application of glutamate was used to assess synaptically evoked activity in the C2C12 myotubes. Shortly after glutamate administration, the number of large EPPs (i.e., $>1.5 \mathrm{mV}$ ) increased significantly, whereas the amplitude and number of small EPPs (i.e., $<1.5 \mathrm{mV}$ ) remained relatively unchanged (Fig. 8 , compare $B, C)(n=3)$. Bath application of $5 \mu \mathrm{M}$ TTX almost completely blocked the large EPPs but had no effect on either the number or amplitude of the small EPPs (Fig. $8 C)(n=3)$. This indicates that the small EPPs are likely spontaneously released miniature EPPs (MEPPs), whereas the large EPPs more closely resemble responses from evoked neurotransmitter release.

To ascertain whether the formation of functional synapses was restricted to muscle cell lines, RA-Hh-Ag-treated ES cells were also cocultured with primary myotubes isolated from embryonic chick muscles. In all myotubes recorded near the EB $(n=13)$, application of $10 \mu \mathrm{M}$ glutamate resulted in large and small EPPs in chick myotubes after $6 \mathrm{~d}$ in coculture (Fig. $8 D$ ). Furthermore, both the large and small EPPs were completely blocked shortly after the application of D-tubocurarine (50 $\mu \mathrm{M} ;<5$ min; $n=3$ ) (Fig. $8 D$ ). EPPs were never recorded from chick myotubes located $>5 \mathrm{~mm}$ from the treated ES cells even when glutamate was added to the cocultures (data not shown). Together, these results indicate that RA-Hh-Ag-treated ES cells can form functional synapses with both $\mathrm{C} 2 \mathrm{C} 12$ cells and primary chick myotubes and that the EPPs recorded from the muscle fibers are mediated by nicotinic acetylcholine receptors.

\section{Discussion}

The differentiation of specific classes of neurons from ES cells is a critical step toward the development of cell replacement therapies for neurodegenerative diseases in which discrete populations of neurons are lost. To define a specific class of neurons, one must use a combination of molecular and functional properties. Previous studies have shown that ES cells exposed to RA and Hh-Ag express molecular markers characteristic of MNs (Fig. 2) (Wichterle et al., 2002). Moreover, after transplantation into the spinal cord of chick embryos, ES cellderived MNs have been shown to survive and project axons to muscle fibers (Wichterle et al., 2002). In the present study, we show that ES cell-derived MNs acquire electrophysiological properties characteristic of their embryo-derived counterparts. In particular, ES cell-derived MNs develop appropriate currents in response to neurotransmitters (Fig. 4), can receive synaptic input (Fig. 4Ciii), have the capacity to fire repetitively at rates necessary for functional muscle contraction (Figs. 5, 6), and form functional synapses with cultured muscle cells (Figs. 7, 8).

For neurons to respond to synaptic activity, it is necessary that they develop the neurotransmitter receptors appropriate for their cell type. In ES cell-derived MNs, inward currents induced by exogenous application of the major inhibitory neurotransmitters of the spinal cord, GABA and glycine, demonstrated the expression of appropriate functional neurotransmitter receptors. Our findings are consistent with studies of developing spinal MNs demonstrating $\mathrm{Cl}^{-}$-mediated currents in response to GABA and glycine receptor activation (Wu et al., 1992; Gao and ZiskindConhaim, 1995). Interestingly, we found that the magnitudes of steady-state GABA-induced currents were greater than those induced by glycine. A conclusion regarding the relative current densities is complicated by the likelihood of receptor desensitization during bath application of agonists, which will lead to underestimation of the measurement of peak current magnitudes. In developing MNs, however, GABA-mediated currents are also 

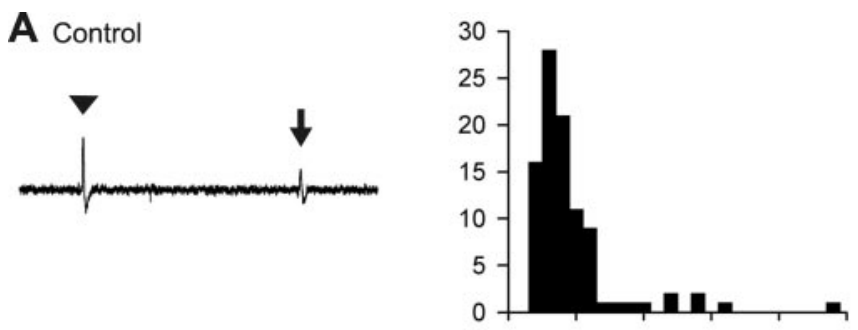

B Glutamate $(100 \mu \mathrm{M})$
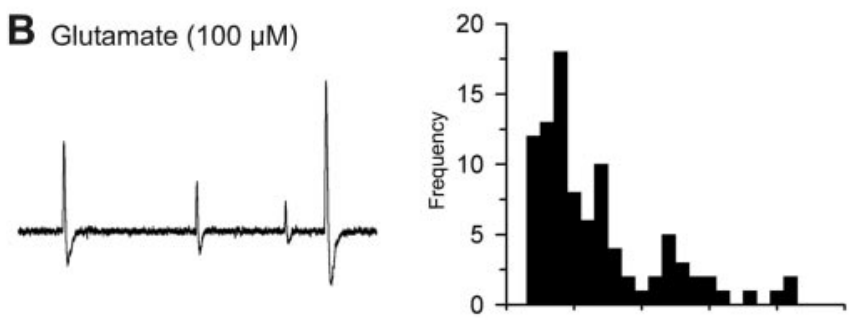

C Glutamate \& TTX $(5 \mu \mathrm{M})$

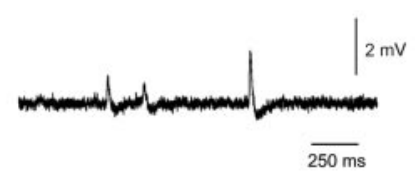

Glutamate $(100 \mu \mathrm{M})$
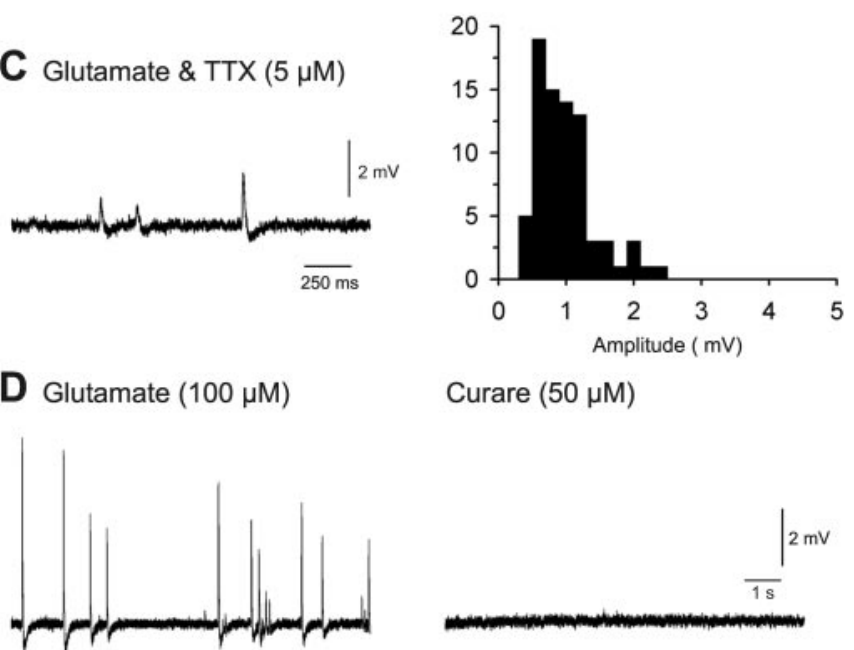

Curare $(50 \mu \mathrm{M})$

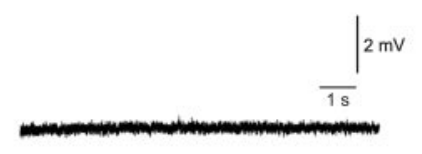

Figure 8. ES cell-derived MNs form functional connections with muscle cells. Representative postsynaptic intracellular sharp electrode recordings from $C 2 C 12$ myotube cocultures $(A$, left) revealed a high number of MEPPs (i.e., amplitude $<1.5 \mathrm{mV}$ ) and relatively few EPPs (i.e., amplitudes $>1.5 \mathrm{mV})(A$, right). Application of $100 \mu \mathrm{m}$ glutamate caused an expected increase in the number of EPPs $(B)$, whereas the addition of $5 \mu \mathrm{M}$ TTX blocked most EPPS $(C)$. The frequency histograms in $A-C$ were generated from $\approx 90$ sec recordings. Similar responses to glutamate application were recorded from chick myotubes cocultured with ES cell-derived MNs (D, left). EPPs were blocked entirely by $50 \mu \mathrm{m}$ D-tubocurarine ( $D$, right).

larger than those mediated by glycine, likely reflecting expression of a greater number of GABA channels (Gao and ZiskindConhaim, 1995). During development, an increase in glycine receptor density leads to equivalent GABA- and glycine-mediated current magnitudes by postnatal stages (Gao and ZiskindConhaim, 1995). These data suggest that ES cell-derived MNs acquire a late embryonic stage MN identity.

ES cell-derived MNs also expressed functional receptors necessary to receive excitatory inputs, as evidenced by inward currents in response to glutamate applications. The shape of the $I-V$ relationship for glutamate-induced currents was consistent with activation of both NMDA and non-NMDA receptors (Mayer and Westbrook, 1984; Westbrook and Mayer, 1984). The expression of functional glutamate receptors on ES cell-derived MNs enabled the use of glutamate applications to stimulate synaptic activity on muscle cells in coculture (discussed below). Furthermore, glutamate application evoked EPSCs in ES cell-derived MNs after $6 \mathrm{~d}$ in coculture, demonstrating the development of functional synapses on these cells.
ES cell-derived MNs not only developed the receptors required to receive inputs, but also developed the membrane conductances required to transform inputs into appropriate patterns of action potential firing. ES cell-derived MNs expressed a range of ion channels, including fast-inactivating $\mathrm{Na}^{+}$channels, delayed rectifier $\left(I_{\mathrm{K}}\right.$-type $) \mathrm{K}^{+}$channels, transient $\left(I_{\mathrm{A}}\right.$-type $) \mathrm{K}^{+}$ channels, and voltage-activated $\mathrm{Ca}^{2+}$ channels. Currents mediated by these channels were consistent with those reported in embryonic and early postnatal MNs developing in vivo (Takahashi, 1990; Gao and Ziskind-Conhaim, 1998; Alessandri-Haber et al., 2002). Electrophysiological studies of undefined ES cellderived neurons have also demonstrated expression of some of these currents (Bain et al., 1995; Strubing et al., 1995, 1997; Benninger et al., 2003), suggesting that their development is intrinsic to the development of a neuronal identity. In addition, ES cellderived dopaminergic neurons after transplantation also develop voltage-activated currents similar to those seen in cultured dopaminergic neurons (Kim et al., 2002), indicating some specificity in channel development. We demonstrate that ES cell-derived MNs assume the electrophysiological properties of spinal MNs. For example, they express $\mathrm{Ca}_{\mathrm{V}} 1$ (L-type) voltage-activated $\mathrm{Ca}^{2+}$ channels, which develop in MNs during the first 2 postnatal weeks in mice (Jiang et al., 1999) and are thought to be important in the generation of output from spinal MNs through their contribution to bistable membrane behavior (Hounsgaard and Kiehn, 1989; Jiang et al., 1999; Carlin et al., 2000b; Heckman et al., 2003). L-type channel activation using FPL-64176 induced sustained depolarizations in ES cell-derived MNs, supporting the presence of dendritic $\mathrm{Ca}^{2+}$ channels that are thought to underlie bistable membrane behavior in MNs (Carlin et al., 2000b). This suggests that these cells have acquired a postnatal phenotype.

The profile of ion channels expressed by MNs enables them to generate trains of action potentials of appropriate firing frequency to effect muscle contraction (Granit et al., 1963). ES cellderived MNs generated repetitive action potential firing after $3 \mathrm{~d}$ in coculture. Steady-state firing frequencies of up to $20 \mathrm{~Hz}$ were detected in ES cell-derived MNs. These rates are in the appropriate range for developing MNs (Martin-Caraballo and Greer, 1999) as well as adult type slow MNs (Kernell et al., 1983). In contrast, other spinal neurons such as dorsal spinocerebellar tract neurons (cat) (Gustafsson, 1984) or unidentified ventral interneurons (turtle) (McDonagh et al., 1998) fire at much higher frequencies. Another feature of normal MN firing evident in ES cell-derived MNs was spike frequency adaptation. The shorter initial interspike interval, typically seen in MNs, may help to stimulate extra force at the beginning of muscular contraction (Stein and Parmiggiani, 1979).

Interestingly, only single action potentials could be elicited in ES cell-derived MNs during the first $2 \mathrm{~d}$ in coculture. This finding parallels recordings of embryonic lumbar spinal MNs in which only single action potentials are generated (Gao and ZiskindConhaim, 1998). By early postnatal stages in vivo, repetitive firing is observed in lumbar MNs, much like ES cell-derived MNs grown for longer periods. These data suggest that ES cell-derived MNs exhibit an early postnatal character.

An additional criterion that defines MNs is the ability to form functional connections with muscle cells. Anatomical evidence of connections between ES cell-derived MNs and muscle fibers was provided after grafting of ES cell-derived MNs in the embryonic chick spinal cord (Wichterle et al., 2002). Endplate potentials have been reported in cocultures of neuronal precursor cells with myocytes (MacDonald et al., 2003). Furthermore, in cocultures of ES cell-derived MNs and C2C12-derived myotubes, there is 
evidence of myotube innervation and nicotinic acetylcholine receptor-dependent contraction (Mizuseki et al., 2003; Harper et al., 2004). In the present study, we provided anatomical and physiological evidence of connections between ES cell-derived MNs and muscle cells in culture. eGFP-positive axons contact $\mathrm{C} 2 \mathrm{C} 12$ myotubes and induce acetylcholine receptor clustering on myotubes in close proximity to eGFP-positive axons. Recordings of myotubes in coculture with ES cell-derived MNs revealed nicotinic receptor-dependent EPPs. Moreover, a TTX-sensitive increase in the frequency and amplitude of EPPs in response to glutamate indicated that the EPPs resulted from synaptic connections between ES cell-derived MNs and myotubes.

Together, our findings indicate that cholinergic MNs generated from ES cells in culture express functional neurotransmitter receptors, receive synaptic inputs, develop ionic currents necessary to convert inputs to appropriate patterns of action potential firing, and form functional synapses with muscle cells. In addition, the preponderance of evidence indicates that by $5 \mathrm{~d}$ in coculture, they have acquired a postnatal functional phenotype. These data provide additional evidence that ES cell-derived MNs recapitulate the normal program of MN development in vitro. This experimental system therefore provides a valuable model for studying intrinsic and extrinsic factors that influence functional aspects of MN excitability. Furthermore, the demonstration that ES cell-derived MNs develop functional properties and form functional synapses may be of relevance in attempts to develop cell replacement therapies in diseases that involve $\mathrm{MN}$ degeneration.

\section{References}

Alessandri-Haber N, Alcaraz G, Deleuze C, Jullien F, Manrique C, Couraud F, Crest M, Giraud P (2002) Molecular determinants of emerging excitability in rat embryonic motoneurons. J Physiol (Lond) 541:25-39.

Arber S, Han B, Mendelsohn M, Smith M, Jessell TM, Sockanathan S (1999) Requirement for the homeobox gene $\mathrm{Hb} 9$ in the consolidation of motor neuron identity. Neuron 23:659-674.

Arenas E (2002) Stem cells in the treatment of Parkinson's disease. Brain Res Bull 57:795-808.

Bain G, Kitchens D, Yao M, Huettner JE, Gottlieb DI (1995) Embryonic stem cells express neuronal properties in vitro. Dev Biol 168:342-357.

Baldissera F, Gustafsson B (1971) Regulation of repetitive firing in motoneurones by the afterhyperpolarization conductance. Brain Res 30:431-434.

Benninger F, Beck H, Wernig M, Tucker KL, Brustle O, Scheffler B (2003) Functional integration of embryonic stem cell-derived neurons in hippocampal slice cultures. J Neurosci 23:7075-7083.

Binder MD, Heckman CJ, Powers RK (1996) The physiological control of motoneuron activity. In: Handbook of physiology (Rowell LB, Shepherd JT, eds), pp 3-53. New York: Oxford.

Briscoe J, Pierani A, Jessell TM, Ericson J (2000) A homeodomain protein code specifies progenitor cell identity and neuronal fate in the ventral neural tube. Cell 101:435-445.

Brownstone RM, Jordan LM, Kriellaars DJ, Noga BR, Shefchyk SJ (1992) On the regulation of repetitive firing in lumbar motoneurones during fictive locomotion in the cat. Exp Brain Res 90:441-455.

Caceres A, Binder LI, Payne MR, Bender P, Rebhun L, Steward O (1984) Differential subcellular localization of tubulin and the microtubuleassociated protein MAP2 in brain tissue as revealed by immunocytochemistry with monoclonal hybridoma antibodies. J Neurosci 4:394-410.

Carlin KP, Jiang Z, Brownstone RM (2000a) Characterization of calcium currents in functionally mature mouse spinal motoneurons. Eur J Neurosci 12:1624-1634.

Carlin KP, Jones KE, Jiang Z, Jordan LM, Brownstone RM (2000b) Dendritic L-type calcium currents in mouse spinal motoneurons: implications for bistability. Eur J Neurosci 12:1635-1646.

Chen XL, Zhong ZG, Yokoyama S, Bark C, Meister B, Berggren PO, Roder J, Higashida H, Jeromin A (2001) Overexpression of rat neuronal calcium sensor-1 in rodent NG108-15 cells enhances synapse formation and transmission. J Physiol (Lond) 532:649-659.

Curtis DR, Hosli L, Johnston GA, Johnston IH (1968) The hyperpolarization of spinal motoneurones by glycine and related amino acids. Exp Brain Res 5:235-258.

Dahm LM, Landmesser LT (1991) The regulation of synaptogenesis during normal development and following activity blockade. J Neurosci 11:238-255.

Dutia MB, Johnston AR (1998) Development of action potentials and apamin-sensitive after-potentials in mouse vestibular nucleus neurones. Exp Brain Res 118:148-154.

Freed CR (2002) Will embryonic stem cells be a useful source of dopamine neurons for transplant into patients with Parkinson's disease? Proc Natl Acad Sci USA 99:1755-1757.

Gao BX, Ziskind-Conhaim L (1995) Development of glycine- and GABAgated currents in rat spinal motoneurons. J Neurophysiol 74:113-121.

Gao BX, Ziskind-Conhaim L (1998) Development of ionic currents underlying changes in action potential waveforms in rat spinal motoneurons. J Neurophysiol 80:3047-3061.

Gerlach M, Braak H, Hartmann A, Jost WH, Odin P, Priller J, Schwarz J (2002) Current state of stem cell research for the treatment of Parkinson's disease. J Neurol 249 [Suppl 3]:III/33-35.

Gilmor ML, Nash NR, Roghani A, Edwards RH, Yi H, Hersch SM, Levey AI (1996) Expression of the putative vesicular acetylcholine transporter in rat brain and localization in cholinergic synaptic vesicles. J Neurosci 16:2179-2190.

Granit R, Kernell D, Shortess GK (1963) Quantitative aspects of repetitive firing of mammalian motoneurones, caused by injected currents. J Physiol (Lond) 168:911-931.

Gustafsson B (1984) Afterpotentials and transduction properties in different types of central neurones. Arch Ital Biol 122:17-30.

Harper JM, Krishnan C, Darman JS, Deshpande DM, Peck S, Shats I, Backovic S, Rothstein JD, Kerr DA (2004) Axonal growth of embryonic stem cellderived motoneurons in vitro and in motoneuron-injured adult rats. Proc Natl Acad Sci USA 101:7123-7128.

Heckman CJ, Lee RH, Brownstone RM (2003) Hyperexcitable dendrites in motoneurons and their neuromodulatory control during motor behavior. Trends Neurosci 26:688-695.

Heineman SH (1995) Guide to data acquisition and analysis. In: Singlechannel recording, Ed 2 (Sakmann B, Neher E, eds), pp 53-91. New York: Plenum.

Hounsgaard J, Kiehn O (1989) Serotonin-induced bistability of turtle motoneurones caused by a nifedipine-sensitive calcium plateau potential. J Physiol (Lond) 414:265-282.

Jiang Z, Rempel J, Li J, Sawchuk MA, Carlin KP, Brownstone RM (1999) Development of L-type calcium channels and a nifedipine-sensitive motor activity in the postnatal mouse spinal cord. Eur J Neurosci 11:3481-3487.

Jiang ZG, Shen E, Dun NJ (1990) Excitatory and inhibitory transmission from dorsal root afferents to neonate rat motoneurons in vitro. Brain Res 535:110-118.

Kawasaki H, Mizuseki K, Nishikawa S, Kaneko S, Kuwana Y, Nakanishi S, Nishikawa SI, Sasai Y (2000) Induction of midbrain dopaminergic neurons from ES cells by stromal cell-derived inducing activity. Neuron 28:31-40.

Kernell D, Eerbeek O, Verhey BA (1983) Relation between isometric force and stimulus rate in cat's hindlimb motor units of different twitch contraction time. Exp Brain Res 50:220-227.

Kim JH, Auerbach JM, Rodriguez-Gomez JA, Velasco I, Gavin D, Lumelsky N, Lee SH, Nguyen J, Sanchez-Pernaute R, Bankiewicz K, McKay R (2002) Dopamine neurons derived from embryonic stem cells function in an animal model of Parkinson's disease. Nature 418:50-56.

Klocker N, Oliver D, Ruppersberg JP, Knaus HG, Fakler B (2001) Developmental expression of the small-conductance $\mathrm{Ca}(2+)$-activated potassium channel SK2 in the rat retina. Mol Cell Neurosci 17:514-520.

Lee SH, Lumelsky N, Studer L, Auerbach JM, McKay RD (2000) Efficient generation of midbrain and hindbrain neurons from mouse embryonic stem cells. Nat Biotechnol 18:675-679.

Lupa MT, Hall ZW (1989) Progressive restriction of synaptic vesicle protein to the nerve terminal during development of the neuromuscular junction. J Neurosci 9:3937-3945.

MacDonald SC, Fleetwood IG, Hochman S, Dodd JG, Cheng GK, Jordan LM, 
Brownstone RM (2003) Functional motor neurons differentiating from mouse multipotent spinal cord precursor cells in culture and after transplantation into transected sciatic nerve. J Neurosurg 98:1094-1103.

Martin-Caraballo M, Greer JJ (1999) Electrophysiological properties of rat phrenic motoneurons during perinatal development. J Neurophysiol 81:1365-1378.

Martin-Caraballo M, Greer JJ (2001) Voltage-sensitive calcium currents and their role in regulating phrenic motoneuron electrical excitability during the perinatal period. J Neurobiol 46:231-248.

Mayer ML, Westbrook GL (1984) Mixed-agonist action of excitatory amino acids on mouse spinal cord neurones under voltage clamp. J Physiol (Lond) 354:29-53.

McDonagh JC, Gorman RB, Gilliam EE, Hornby TG, Reinking RM, Stuart DG (1998) Properties of spinal motoneurons and interneurons in the adult turtle: provisional classification by cluster analysis. J Comp Neurol 400:544-570.

McLarnon JG (1995) Potassium currents in motoneurones. Prog Neurobiol 47:513-531.

Mizuseki K, Sakamoto T, Watanabe K, Muguruma K, Ikeya M, Nishiyama A, Arakawa A, Suemori H, Nakatsuji N, Kawasaki H, Murakami F, Sasai Y (2003) Generation of neural crest-derived peripheral neurons and floor plate cells from mouse and primate embryonic stem cells. Proc Natl Acad Sci USA 100:5828-5833.

Novitch BG, Wichterle H, Jessell TM, Sockanathan S (2003) A requirement for retinoic acid-mediated transcriptional activation in ventral neural patterning and motor neuron specification. Neuron 40:81-95.

Papasozomenos SC, Binder LI, Bender PK, Payne MR (1985) Microtubuleassociated protein 2 within axons of spinal motor neurons: associations with microtubules and neurofilaments in normal and beta,beta' iminodipropionitrile-treated axons. J Cell Biol 100:74-85.

Rafuse VF, Landmesser L (1996) Contractile activity regulates isoform expression and polysialylation of NCAM in cultured myotubes: involvement of $\mathrm{Ca}^{2+}$ and protein kinase C. J Cell Biol 132:969-983.

Renoncourt Y, Carroll P, Filippi P, Arce V, Alonso S (1998) Neurons derived in vitro from ES cells express homeoproteins characteristic of motoneurons and interneurons. Mech Dev 79:185-197.

Reubinoff BE, Itsykson P, Turetsky T, Pera MF, Reinhartz E, Itzik A, Ben-Hur
T (2001) Neural progenitors from human embryonic stem cells. Nat Biotechnol 19:1134-1140.

Silani V, Fogh I, Ratti A, Sassone J, Ciammola A, Cova L (2002) Stem cells in the treatment of amyotrophic lateral sclerosis (ALS). Amyotroph Lateral Scler Other Motor Neuron Disord 3:173-181.

Stein RB, Parmiggiani F (1979) Optimal motor patterns for activating mammalian muscle. Brain Res 175:372-376.

Stein V, Hermans-Borgmeyer I, Jentsch TJ, Hubner CA (2004) Expression of the $\mathrm{KCl}$ cotransporter $\mathrm{KCC} 2$ parallels neuronal maturation and the emergence of low intracellular chloride. J Comp Neurol 468:57-64.

Strubing C, Ahnert-Hilger G, Shan J, Wiedenmann B, Hescheler J, Wobus AM (1995) Differentiation of pluripotent embryonic stem cells into the neuronal lineage in vitro gives rise to mature inhibitory and excitatory neurons. Mech Dev 53:275-287.

Strubing C, Rohwedel J, Ahnert-Hilger G, Wiedenmann B, Hescheler J, Wobus AM (1997) Development of $\mathrm{G}$ protein-mediated $\mathrm{Ca}^{2+}$ channel regulation in mouse embryonic stem cell-derived neurons. Eur J Neurosci 9:824-832.

Takahashi T (1990) Membrane currents in visually identified motoneurones of neonatal rat spinal cord. J Physiol (Lond) 423:27-46.

Thaler J, Harrison K, Sharma K, Lettieri K, Kehrl J, Pfaff SL (1999) Active suppression of interneuron programs within developing motor neurons revealed by analysis of homeodomain factor HB9. Neuron 23:675-687.

Werman R, Davidoff RA, Aprison MH (1968) Inhibitory action of glycine on spinal neurons in the cat. J Neurophysiol 31:81-95.

Westbrook GL, Mayer ML (1984) Glutamate currents in mammalian spinal neurons: resolution of a paradox. Brain Res 301:375-379.

Wichterle H, Lieberam I, Porter JA, Jessell TM (2002) Directed differentiation of embryonic stem cells into motor neurons. Cell 110:385-397.

Wu WL, Ziskind-Conhaim L, Sweet MA (1992) Early development of glycine- and GABA-mediated synapses in rat spinal cord. J Neurosci 12:3935-3945.

Zhang L, Krnjevic K (1987) Apamin depresses selectively the afterhyperpolarization of cat spinal motoneurons. Neurosci Lett 74:58-62.

Zhang SC, Wernig M, Duncan ID, Brustle O, Thomson JA (2001) In vitro differentiation of transplantable neural precursors from human embryonic stem cells. Nat Biotechnol 19:1129-1133. 